\title{
RELATION BETWEEN TIROID STATUS WITH GLYCEMIC CONTROL OF TYPE 2 DM PATIENTS AT RSPAD GATOT SOEBROTO
}

\author{
Kartika Yulianti' ${ }^{1}$, Aris Wibudi²), Mila Citrawati3) \\ 1)Faculty of Medicine, UPN Veteran, Jakarta \\ 2)Department of Internal Medicine, Faculty of Medicine, UPN Veteran, Jakarta \\ ${ }^{3)}$ Department of Faal, Faculty of Medicine, UPN Veteran, Jakarta
}

\begin{abstract}
Background: Diabetes Mellitus (DM) is a group of symptoms that arise due to increased blood sugar levels. Diabetes Mellitus type 2 has a higher risk of developing thyroid dysfunction. Thyroid dysfunction can affect various body metabolism and result in insulin resistance, significantly affecting glycemic control in DM patients. This study aimed to determine the relation between thyroid status as assessed by the level of thyroid-stimulating hormone (TSH), free thyroxine (FT4), and glycemic control (HbA1c).

Subjects and Method: A cross-sectional study. A sample of $38 \mathrm{DM}$ patients was selected by purposive sampling. The dependent variable was glycemic control. The independent variables were TSH and FT4. Patients were classified into 4 quartiles (Q) based on their TSH and FT4 levels. Statistic test used was non parametric for category group of variables, which was Chi square test.

Results: Mean of fasting blood glucose was 200,56 mg/dL (modus $137 \mathrm{mg} / \mathrm{dL}$ ), mean of 2 hours post prandial blood glucose was $247 \mathrm{mg} / \mathrm{dL}$ (modus $305 \mathrm{mg} / \mathrm{dL}$ ). Subjetcs with poor glycemic control dominated as much as 76\%. Most subjects had TSH level at Q4 (36\%), while most of the subjects had FT4 level at Q1 (34\%). The results showed that 38 samples with poor glycemic control were $72 \%$ in the 4 th quartile (Q4) (> 3.1750 mU / L) TSH, and 64.7\% were in Q1 (s 11.8400) FT4. The analysis showed that there was a significant relation between TSH $(p=0.047)$ and FT4 ( $\mathrm{p}=0.041)$ with glycemic control in type 2 DM patients.
\end{abstract}

Conclusion: FT4 and TSH levels relate to glycemic control in type 2 DM patients

Keywords: TSH, FT4, HbA1c, Diabetes Mellitus

Correspondence:

Mila Citrawati. Department of Faal, Faculty of Medicine, UPN Veteran, Jakarta. Jl. RS Fatmawati, Pondok Labu, South Jakarta 12450, Telp. (o21) 7656971. E-mail: milacitrawati@upnvj.ac.id. Mobile: 081282990515

The $7^{\text {th }}$ International Conference on Public Health Solo, Indonesia, November 18-19, 2020 | 380 https://doi.org/10.26911/the7thicph.05.12 